\title{
9
}

\section{Jamski turizem kot vir dohodkov na podeželju: Kras in Postojna (17.-19. stoletje)}

\author{
Petra Kavrečič \\ Univerza na Primorskem \\ Fakulteta za humanistične študije \\ Titov $\operatorname{trg}$ 5, 6000 Koper \\ petra.kavrecic@fhs.upr.si
}

\section{Uvod}

Turizem danes predstavlja eno najhitreje rastočih gospodarskih panog na svetu. Na območju Krasa, ki je predmet obravnave, je bil turizem v svojih "predhodnih" oblikah - prototurizem - prisoten predvsem od zgodnjega novega veka dalje. Govorimo zlasti o popotnikih, tujih obiskovalcih, ki so se zanimali za nenavadne narave pojave in se podali v temno podzemlje kraških jam. O »turistih" predmoderne dobe je na podlagi potopisov in popotniških dnevnikov zbranega in objavljenega precej gradiva (glej na primer Shaw 2008; Shaw in Čuk 2015; Kavrečič 2015a; 2016), kjer dobimo tudi drobce informacij o domačinih, ki so »turistom« omogočili obisk jam. Lokalni prebivalci so bili pogosto tudi edini stik, ki so ga imeli obiskovalci z okolico.

Pred pojavom organizirane vodniške jamske službe in regulacijo cen za posamezne storitve so namreč popotniki, ki so želeli obiskati podzemlje, najpogosteje prihajali $\mathrm{v}$ stik $\mathrm{z}$ domačini, to je kmeti iz okoliških vasi. Lokalni prebivalci so bili seznanjeni s podzemnim svetom - v bistvu so bili edini, ki so lahko obiskovalce pospremili po še neurejenih, temnih, spolzkih in zato nevarnih poteh. Ob vodenju so jim nudili tudi razsvetljavo. Te storitve so bile plačljive, kar pomeni, da so kmetje za to uslugo prejeli določeno finančno retribucijo.

Prispevek se osredotoča na vprašanje, ali je potovanje v preindustrijski in industrijski dobi vplivalo na razvoj neagrarnih dejavnosti na Krasu. 
Preverja, ali je turizem (in njegove predmoderne oblike) vplival na ponudbo storitev kmečkega prebivalstva, vezanih na to dejavnost, in sicer v okolici turistično atraktivnih krajev, ter v kolikšni meri je lokalno prebivalstvo izkoriščalo tovrstne priložnosti, se vključevalo v ponudbo kot vodniki in svetilničarji po podzemlju ter na ta način integriralo kmetijske vire dohodka s tistimi iz terciarnega sektorja.

Večino podatkov o tej obliki kmečke ekonomije lahko razberemo iz potopisnih dnevnikov in sorodnega gradiva, ni pa to dejavnost, ki bi bila kjerkoli uradno registrirana. Ti zapisi najpogosteje omenjajo lokalnega kmeta (kmete) kot vodnika do in po jami ter svetilničarja. V industrijski dobi, ko pride do organizacije turistične ponudbe tudi na področju jamskega turizma, je na razpolago nekoliko več virov, iz katerih lahko črpamo informacije, kot so lokalno časopisje, turistični vodiči oz. potovalni priročniki, poročila in objave upraviteljev jam ter razno promocijsko gradivo, kjer so objavljene informacije o cenah za vstopnino, vodenje, razsvetljavo, podatki o nastanitvah in ponudnikih gostinskih storitev. Omenjajo se tudi dostopnost in možnosti obiska (urnik odprtja jam, plačilo za vodnika), nekateri potovalni priročniki poleg tega navajajo vključenost lokalnega podeželskega prebivalstva $\mathrm{v}$ turistično ponudbo (vodenje, preskrba hotelov s hrano, sezonsko delo, prevozne storitve itd.). Kljub temu pa vse do strokovne organizacije turističnega sektorja s tečaji in $\mathrm{z}$ izobraževalnimi ustanovami s področja turizma, ki so oblikovali profile turističnih delavcev (natakar, kuhar, hotelski delavec ...), ne moremo natančno določiti oz. kvantitavno opredeliti pomena teh dejavnosti v skupnem dohodku gospodinjstev. V tem primeru bomo analizirali, ali je bil interes za vključevanje $\mathrm{v}$ ta proces $\mathrm{s}$ strani kmečkega prebivalstva prisoten $\mathrm{v}$ predindustrijski in industrijski dobi ter ali se je $\mathrm{v}$ obeh obdobjih interes za to dejavnost spreminjal (naraščal, upadal).

\section{Jamski turizem}

Kras že v svojem imenu nosi opis pokrajine, ki pomeni kamnit svet, sami opisi kraške krajine pa so v preteklosti označevali predvsem »veliko dela in truda, malo zemlje in veliko kamenja, preveč burje in premalo vode« (Panjek 2015, 21). ${ }^{1}$ Težki pogoji za obdelovanje zemlje in skromen pride-

1 Prim. Louis-Francois Cassas, francoski krajinski slikar: »In these districts, highly-cultivated land is no longer to be seen: the soil is gravelly, dry, and barren, and from Senosequia to the valley of the Ruecca its appearance was melancholy in the extreme«, Lavallée 1805, 122. 
lek nista zadoščala za preživetje, zato so si kmetje vire dohodka iskali tudi drugje kot v prevozništvu, kmečki trgovini in tihotapstvu (Panjek 2014, 200-1). Ne glede na 'neprijazno' okolje je zlasti podzemni jamski svet že v preteklosti privabljal radovedne avanturiste in raziskovalce, zato lahko trdimo, da je ravno jamski turizem na obravnavanem območju najstarejša tovrstna dejavnost na svetu (Kavrečič 2015c). Ta izkazani interes je kmečkemu prebivalstvu na Krasu ponujal možnosti za dodatni vir dohodka iz terciarnega sektorja.

Prebivalci, ki so živeli v bližini jam, so bili z okolico dobro seznanjeni. Nekateri so lahko obiskovalce tudi vodili po jamskem podzemlju. Vodniku je slednji uslugo povrnil z določenim plačilom. Bolj kot je bila jama poznana in dostopna, večji je bil obisk. Iz navedenih razlogov je največ podatkov za zgodnji novi vek dostopnih za jamo Vilenico (Lokev pri Divači), ki je znana tudi kot najstarejša »turistična« jama na Slovenskem. Status najbolj znane in obiskane jame je ohranila do začetka 19. stoletja. V njenem primeru gre za prvo znano komercialno jamo, saj so njeni lastniki (grofje Petazzi/Petači) domnevno že leta 1633 uvedli vstopnino (Shaw in Čuk 2015, 397; Habe in Kranjc 1981, 29). Plačilo za vodnika, vodnike in svetilničarje je bilo poznano tudi v drugih jamah, vstopnina pa ne. Razlogi za uvedbo vstopnine so bili večstranski, saj je bil del vstopnine namenjen blagajni lokavske cerkve (Petači so bili dolžniki cerkve, darovali so maše za varnost v jami; Puc 2000, 22; Agapito 1823), kljub temu pa gre zagotovo za komercialno aktivnost, ki je lastnikom prinašala dohodke. Poleg jame Vilenica so bile v predindustrijski dobi obiskane tudi Črna jama (Magdalena), Predjama, Zelška jama, Križna jama, Briška jama (Grotta Gigante), vendar je o obiskih ohranjenih manj poročil oz. obisk najverjetneje ni bil tako velik kot $\mathrm{v}$ primeru Vilenice. $\mathrm{V}$ dobi industrializacije pa pridejo $\mathrm{v}$ ospredje predvsem Postojnska in Škocjanske jame ter deloma tudi novoodkrita Divaška jama (Shaw 2008; Kavrečič 2015c).

Jamskemu turizmu, kot eni izmed najstarejših in najposebnejših turističnih dejavnosti na Slovenskem, je bila posvečena že precejšnja pozornost. Raziskave so (bile) osredotočene zlasti na razloge za obisk, obiskovalce same (objave popotniških dnevnikov), razvoj in postavitev turistične infrastrukture (zlasti v moderni dobi) in ponudbe ter statistiko obiska (Postojnska jama). Interes je bil namenjen tudi sami zgodovini raziskav podzemlja in urejanja poti po jamah (Škocjanske jame). Najpogosteje so obravnavane jame Vilenica (predindustrijska doba), Škocjanske in Postojnska jama (glej Čuk, Kavrečič, Kranjc, Puc, Savnik, Shaw in drugi), ki so turistično tudi 
najprepoznavnejše. Zanimanje za vpliv te dejavnosti na lokalno ekonomijo pa je zanemarjena tema, čemur je najverjetneje botrovalo tudi pomanjkanje virov. V pričujočem prispevku me zanima, kolikšna je bila vključenost lokalnega kmečkega prebivalstva $\mathrm{v}$ ponudbo turističnih storitev. Osrednji storitvi, ki sta bili povezani z jamskim turizmom, sta bili vodenje in nudenje razsvetljave.

\section{Jamski vodniki pred organizacijo turistične infrastrukture}

$\mathrm{V}$ dnevnikih in sorodnih zapisih so popotniki poleg opisov podzemlja, krajine in načina življenja domačinov navedli tudi podatke o dostopnosti, poteh, poznavanju tujih jezikov s strani gostiteljev, nastanitvi, prehrani, morebitnih težavah in nevšečnostih ter nenazadnje o vodnikih in svetilničarjih, ki so jih pospremili v jame. Večinoma pridobimo le informacijo o tem, da so jih $\mathrm{v}$ jamo pospremili oz. po jami vodili domačini iz bližnjih vasi. Najpogosteje dobimo informacije o njihovem številu, vodniških kompetencah in poznavanju podzemlja, vrsti nudene razsvetljave ter o komunikacijskih veščinah (jezik). Za nudeno uslugo so jim obiskovalci plačali, redko pa dobimo podatke o sami višini plačila. Zato lahko sklepamo, da so bili najverjetneje plačani na licu mesta. Čeprav ni mogoče oceniti, kolikšen del lokalnega prebivalstva se je ukvarjal $\mathrm{z}$ vodenjem, je bil vendarle za popotnika zagotovo edini način, da je lahko obiskal podzemlje, ravno spremstvo lokalnega vodnika, dobrega poznavalca bližnje jame.

Kot že omenjeno, je bila v predinustrijski dobi najbolj obiskana jama Vilenica, čemur sta botrovali dobra lokacija ter bližina leta 1580 ustanovljene kobilarne v Lipici. Do jame, ki je bila locirana ob glavni cesti iz Trsta proti Ljubljani in Dunaju, je obiskovalec lahko prišel s poštno kočijo (Agapito 1823, 20). Beneški pisatelj, naturalist in kartograf Alberto Fortis je ob obisku jame leta 1777 ocenil, da je bila prva pomembna prednost jame njena lokacija v bližini poštne poti, ki je olajšala precejšen del poti, ter lahek dostop, saj je bil vhod v jamo preprost in svetel (Kavrečič 2015a, 550). O tem, da je bilo vodnikov navadno več, saj so obiskovalca vodili po poteh in mu nudili tudi razsvetljavo, lahko preberemo v več potopisnih dnevnikih. Že omenjenega Fortisa so v jamo peljali domačini iz vasi Lokev, ki so bili »vajeni voditi tujce $\mathrm{v}$ temne prostore in so za dostop $\mathrm{v}$ jamo uredili priročne kamnite stopnice« (Shaw 2008, 82). Glede na to, da je omenil plezanje dveh od svojih vodnikov, lahko sklepamo, da so z njim odšli vsaj trije domačini. Podatkov o imenih vodnikov ali obliki plačila za njihove usluge v Fortisovih opisih ne dobimo. 
Najem vodnikov leta 1782 omenja tudi francoski krajinski slikar F. L. Cassas, ki jih je potreboval za dostop do bregov reke Reke. ${ }^{2}$ Joseph von Hammer-Purgstall, avstrijski »orientalist«, ki je bil zelo navdušen nad jamo Vilenica, je v svojih zapisih omenil več vodnikov, ki so njega in spremljevalce leta 1798 vodili po jami ter jo razsvetlili z baklami in celo zažigali slamo za boljšo vidljivost. Nekateri vodniki so odšli po poti naprej, zato da so predčasno razsvetlili jamske prostore. Na podlagi njegovih opisov lahko sklepamo, da je bil z vodniškimi sposobnostmi domačinov zadovoljen (Shaw 2008, 90).

Johna Russlla, škotskega pravnika, je leta 1822 do vhoda v Planinsko jamo vodil mlinar. Leta 1828 pa je angleški zdravnik John James Tobin z vodnikom odšel iz Trsta na ogled jame Vilenice. Za sam vstop v jamo je imel več spremljevalcev, človeka, ki je nosil veliko svetilko in nekaj fantov, ki so nosili sveče. Podobno ga je v Škocjanske jame vodil mladenič, ki je govoril malo nemško. V Postojnsko jamo pa so ga vodili trije vodniki, eden izmed njih je govoril nemško (Tobin 1828, 152, 154-5, 159, 168; Shaw 1997, 45). Nedvomno so bili njegovi vodniki in spremljevalci domačini, podrobnejših informacij v svojem dnevniku pa Tobin ni zapustil. Tudi Edmunda Spencerja, nemškega kapitana, je leta 1836 iz Cerknice do Postojnske jame in Predjamskega gradu vodil najeti domačin, a podatka o višini plačila tudi v tem primeru ne dobimo. Eden redkih primerov je nemški pisatelj Johann Gottfried Seume, ki je v svojih zapisih omenil, da je po napornem iskanju razpoložljivih vodnikov oz. domačinov, ki bi ga lahko vodili po Postojnski in Črni jami, le-tem plačal nekaj grošev (Seume 1802, 69-71). Natančnejših podatkov o številu vodnikov pa ne dobimo.

$\mathrm{Ob}$ pojavu turističnih vodičev, kot na primer Murrayevih in Baedekerjevih, se v njih omenjajo lokalni jamski vodniki. Baedekerjev iz leta 1873 navaja, da na Nanos vodi vodnik iz Razdrtega. Baedeker omenja, da so se poleg vodenja ukvarjali še z določenimi postranskimi dejavnostmi, kot je bila prodaja človeških ribic (Proteus anguinus) in kapnikov iz Postojnske jame (Shaw 1997, 45-6), kar bo obravnavano v nadaljevanju.

Pokazano je bilo, da so v predindustrijski dobi tuje obiskovalce vodili domačini, kar se je nadaljevalo tudi v 19. stoletju, ko se že prične spreminjati oz. organizirati ponudba turističnih storitev na tem območju. Ni dvoma, da sta vodenje in nudenje razsvetljave obiskovalcem jame predstavljala vir

2 Škocjanske jame so bile težko dostopne, saj pot ni bila urejena. Tako je do ureditve stopnic večina obiskovalcev ostala zgoraj in občudovala izginotje reke. To so bili, na primer, Kelsall, Hoppe, Hornschuch in Laurent. 
dohodka kmečkemu prebivalstvu, da sta izhajala iz neagrarne dejavnosti že $\mathrm{v}$ predindustrijski dobi ter na ta način vsaj deloma omogočila integracijo osnovnih dohodkov iz kmetijstva s temi iz »turizma«. Ta proces je bil prisoten tudi v primeru drugih naravnih in kulturnih znamenitosti (na primer slapovi, gore). $\mathrm{V}$ tem obdobju pa je zaradi pomanjkljivih podatkov o višini dohodkov iz te dejavnosti ter sami pogostosti nudenja tovrstnih storitev težko ovrednotiti njegovo vlogo. Višina retribucije za vodnike ni nikjer uradno zabeležena, kar se postopoma spremeni $\mathrm{z}$ regulacijo turistične dejavnosti $\mathrm{v}$ jamah: uvedbo vstopnine, cenika za razsvetljavo in vodnike.

\section{Moderni jamski turizem}

Moderni turizem zaznamuje odnos med povpraševanjem in ponudbo storitev na trgu, ki so namenjene turistični dejavnosti. Intenzivnemu razvoju turizma lahko sledimo v obdobju po industrijski revoluciji, saj je povezan $\mathrm{z}$ ekonomskimi, s tehnološkimi ter socialnimi in kulturnimi sprememba$\mathrm{mi}$, ki so ji sledile. Moderni turizem torej predstavlja nadgradnjo in intenzifikacijo preteklih oblik potovanja, kar se je udejanjilo tudi na področju jamskega turizma. Tekom 19. stoletja je ta oblika turizma pridobila pomen na ekonomskem področju, posebej tam, kjer je potekala izgradnja turistične infrastrukture. Razvoj oz. organizacija ponudbe in storitev na področju turizma je intenzivno potekala. Investicije $\mathrm{v}$ ta sektor so predstavljali predvsem izgradnja nastanitvenih in sprostitvenih kapacitet (hoteli, restavracije, parki, gledališča ...) ter organizacija vodenja in upravljanja destinacij, kot so na primer jame. Slednje je na obravnavanem območju potekalo bodisi preko jamskih komisij (Postojna) bodisi preko planinskih društev oz. njihovih jamskih sekcij (Vilenica, Divaška jama, Škocjanske jame). Upravitelji jam so urejali dostopnost v podzemlju (poti, zavarovanje nevarnih odsekov, gradnja mostov), urejali jamsko razsvetljavo, vodniško službo, izdajali cenike za ponujene storitve in na splošno skrbeli za modernizacijo turistične ponudbe. Uvedli so tudi turistično statistiko, ki so jo vodili z vpisnimi knjigami gostov.

Dve turistično danes najprepoznavnejši jami, Postojnska in Škocjanske jame, sta na turistični ponudbi pričeli graditi ravno od začetka 19. stoletja dalje. Takrat je bil odkrit drugi del Postojnske jame in njenega jamskega sistema (Otoška in Črna jama) ter urejen dostop (stopnice) v Škocjanske jame, ki so bile pred tem večinoma občudovane le s površja. Obenem je obisk, zlasti prve, precej olajšala in popularizirala železnica, ki je bila leta 
1857 speljana tudi skozi Postojno. Takrat so se kraju oz. prebivalcem ponudile nove možnosti za pridobivanje prihodkov tudi iz neagrarne dejavnosti (Kavrečič 2015b). Poleg omenjenih dveh so na začetku 19. stoletja za javnost odprli tudi jamo Pečina na Hudem letu pri Padričah, ki jo je leta 1808 vzel v zakup bližnji gostilničar Josip Eggenhöffner, poznan tudi kot eden prvih raziskovalcev podzemlja v Škocjanskih jamah. Podjetni krčmar je tako turistom prvi ponujal ogled omenjene jame in bil hkrati dejaven pri raziskovanju drugih jam (sodeloval je s Svetino pri raziskovanju Škocjanskih jam) ter vodenju avstrijskih in nemških raziskovalcev po kraškem podzemlju (Savnik 1958, 138; Shaw in Čuk 2015, 355).

$\mathrm{V}$ tem obdobju so se dogajale tudi nekatere spremembe $\mathrm{v}$ lastniški strukturi jam, ki so vplivale na nadaljnji razvoj turistične dejavnosti. V drugi polovici 19. stoletja se je namreč lastništvo nad podzemnimi jamami, ki so se najpogosteje nahajale na nekdanji srenjski zemlji, spremenilo. Pred zemljiško odvezo so bila ta območja v lasti fevdalnih gospodov, ki so, kot v primeru Vilenice, jamo tudi tržili. Po letu 1848 pa so pripadla lokalni vaški skupnosti, ki je tedaj lahko pričela upravljati z jamami. Nekatere skupnosti, kot so Vilenica (Lokev), Škocjan in Divača, so izkoristile naravne danosti območja in jame pričele tržiti v turistične namene. Pri tem so bile nekatere bolj, druge manj uspešne. Ne glede na to pa je največji turistični razvoj tekom stoletja doživela jama v Postojni, ki je postala ena izmed osrednjih turističnih atrakcij tedanje Avstrijske monarhije (Avstro-Ogrske). Tako je bil na primer kapnik iz jame razstavljen tudi $\mathrm{v}$ najmondenejšem in najobiskanejšem zdraviliškem letovišču monarhije, Opatiji.

Glede na nadaljnji razvoj tega segmenta turizma, ki se od začetka 19. stoletja dalje konstantno razvija in popularizira, lahko trdimo, da so turistične destinacije že $\mathrm{v}$ tem obdobju odpirale nove možnosti lokalnemu prebivalstvu, da se je aktivno vključil vanje. Organizacija in ureditev infrastrukture ter ponudbe turističnih storitev sta zahtevali precej investicij, angažma javnih in zasebnih akterjev ter seveda delovno silo, ki so jo nedvomno pridobili tudi iz bližnje okolice. Kot bomo pokazali na nekaterih primerih, se je lokalno prebivalstvo na različne načine vključevalo $\mathrm{v}$ turistično dejavnost in si na ta način zagotovilo dodatne vire dohodka.

\subsection{Postojnska jama}

Naključno odkritje domačina Luke Čeča ob postavljanju razsvetljave $\mathrm{v}$ jami za namen obiska avstrijskega cesarja Franca I., ki se je zgodil leta 1818, je Postojno postavil na svetovni zemljevid jamskega turizma in predstavlja 
začetek uspešnega turističnega razvoja. Po odkritju drugega dela jame so domačini poskrbeli za ureditev ogledov in jamo prihodnje leto uradno otvorili za turiste (Čuk 2003; Kariž 2008). Jama je sodila pod postojnski okrajni urad, ki je tudi urejal njeno delovanje, leta 1823 pa je bila ustanovljena jamska komisija, to je upravni organ, ki je vodil jamo. Jamski komisiji je načeloval vsakokratni okrajni glavar Postojne, tudi nekateri drugi člani komisije so bili iz vrst okrajnih uradnikov, in sicer komisar, blagajnik, inženir ter predstavnik postojnskega občinskega odbora. Upravljanje Postojnske jame je bilo torej zaupano javni sferi (Habe 1979, 177). Od leta 1848 pa je jama sodila neposredno pod državno last. Do tega je prišlo zaradi spora glede upravljanja dohodkov iz jamskega sklada. Le-ti so z leti znatno naraščali. Za upravljanje sklada sta se potegovali občina in okraj, zato je vmes posegel cesarjev odlok in jamo podržavil.

Jamska komisija je podobno kot $\mathrm{v}$ primeru zdravilišč zdraviliška komisija prevzela vlogo vodenja turističnega kraja, v tem primeru je skrbela za urejanje poti v jami, gradnjo mostov, odstranjevanje ovir, organizacijo vodniške službe (in plačevanje) in razsvetljave ter vodila knjigo gostov. Z letom 1824 je uradno uvedla jamske vstopnice (Savnik 1958, 142-4).

Ključni moment za nadaljnji uspešni razvoj jamskega turizma $\mathrm{v}$ Postojni je bila izgradnja južne železnice, ki je skozi Postojno vodila potnike od Dunaja do Trsta. Že pred tem je bil kraj sicer na ugodni prometni lokaciji in dobro vključen v mrežo poštnih kočij, a vendarle je železnica iz leta 1857 omogočila hitrejši, cenejši in predvsem množičnejši pretok potnikov. Uspešen turistični razvoj je zahteval dodatne investicije $\mathrm{v}$ turistično infrastrukturo: namestitvene kapacitete (Grand Hotel Adelsberg Franza Proglerja), ureditev okolice, predvsem parkov, drevoredov in sprehajalnih poti za tujce, organizacija vodniške službe, vpeljevanje modernizacije v jamo (železniški tiri v jami leta 1872, električna razsvetljava leta 1884) (Kavrečič 2007; Postojinsko okrajno glavarstvo 1889, 2). Lokalni časopis Notranjec, ki je izhajal med letoma 1904 in 1909, je poročal, da je bilo lokalno prebivalstvo vključeno v ta proces. Poleg vodenja je oskrbovalo postojnske restavracije s pridelki, utrjevalo poti v jami ali izdelovalo mostove ter ponujalo prevoze za turiste (izvoščki; Čeč 2001; Savnik 1960, 103). Od razvoja turizma so prihodke pridobivali tudi prebivalci drugih krajev, kot na primer steklarna na Javorniku pri Suhem vrhu, ki je dobavljala svetilke in olje za potrebe jamske razsvetljave (Savnik 1958, 144).

Če se osredotočimo na jamske vodnike, se že leta 1825 (ob prvi zaprisegi osebja) omenjata dva, Franc Šibenik in Josip Vesel, ki sta hkrati opravlja- 
la tudi funkcijo nadzornika jame. Slednji je bil vodnik zlasti zaradi poznavanja nemškega jezika. Poleg njiju so omenjeni že pomožni vodniki in svetilničarji, prav tako domačini: Luka Čeč, Martin Berne, Miha Križaj, Anton Vuzler, Martin Smrekar in Franc Piskar. Če so pred imenovanjem jamske komisije in regulacijo cen vodniki vodili tujce $v$ jamo po lastnih tarifah in po lastnem urniku, se to kasneje ni več dogajalo. Tarifa za vsako uro vodenja je bila določena na 10 krajcarjev (v nadaljevanju kr.) po osebi. V primeru treh vodnikov, Šibenika, Čeča in Berneta, izvemo, da je bil to njihov edini poklic. Najverjetneje so se zaposlili leta 1825 , s tem pa so izgubili druge potencialne vire prihodkov, kar je z njihove strani sprožilo nejevoljo in pritožbe (na gubernij in celo cesarja). Zahtevali so dosmrtni monopol nad vodniško službo, ki bi jim lahko zagotavljal zadosten vir dohodkov za preživetje družine. Pri tem niso bili uslišani. Dodatni vir dohodka jamskega vodnika je predstavljala še prodaja kapnikov, ki je bila zaradi velikega interesa po nakupu tudi legalizirana, kar pomeni, da so bili vodniki plačani tudi za lomljene kapnikov, ki so odšli v prodajo (Savnik 1958, 1424). Primer postojnskih jamskih vodnikov kaže, kako se je ta poklic profesionaliziral in ni več predstavljal dodatnega vira dohodka, ampak osrednjega. Edinega najverjetneje ne, saj se še sredi stoletja beleži ilegalno postransko dejavnost postojnskih jamskih vodnikov, to je lomljenje in prodaja kapnikov ter človeških ribic na lastno pobudo (Savnik 1960, 102).

Zaradi uspešnega turističnega razvoja, stalnih vlaganj $\mathrm{v}$ modernizacijo infrastrukture in naraščanja števila obiskovalcev so se tudi cene za storitve tekom stoletja spreminjale. Ravno na primeru turistične ponudbe Postojnske jame lahko sledimo precejšnji rasti cen. Ob prvi uradni uvedbi vstopnine leta 1824 je le-ta znašala $24 \mathrm{kr}$. za civiliste in 12 za pripadnike vojske in otroke. Brezplačno je vstopala spremljevalna služinčad. Vsakega obiskovalca sta poleg jamskega vodnika spremljala dva svetilničarja, za katera so gosti plačali 2 goldinarja ( $v$ nadaljevanju gld.). Cena razsvetljave pa je glede na njeno razkošje tudi naraščala: velika razsvetljava je stala 45, mala pa 16 gld., posebna ob obisku cesarja je znašala 225, ob obiskih nadvojvod z Dunaja 18o, za ministre in tuje poslanike pa 90 gld. (Savnik 1958, 142-3).

Schaffenrathov vodič po jami iz leta 1834 že navaja dvig cene za vstopnico, in sicer je le-ta znašala $30 \mathrm{kr}$. za civiliste in polovično ceno za vojake. Cena za razsvetljavo se je še naprej spreminjala glede na vrsto in dolžino obiska: $20 \mathrm{kr}$. so plačali turisti za dvourno razsvetljavo (svetilko), $30 \mathrm{kr}$. za triurno in $40 \mathrm{kr}$. za štiriurno (Schaffenrath 1834, 42; Shaw in Čuk 2015, 236). 


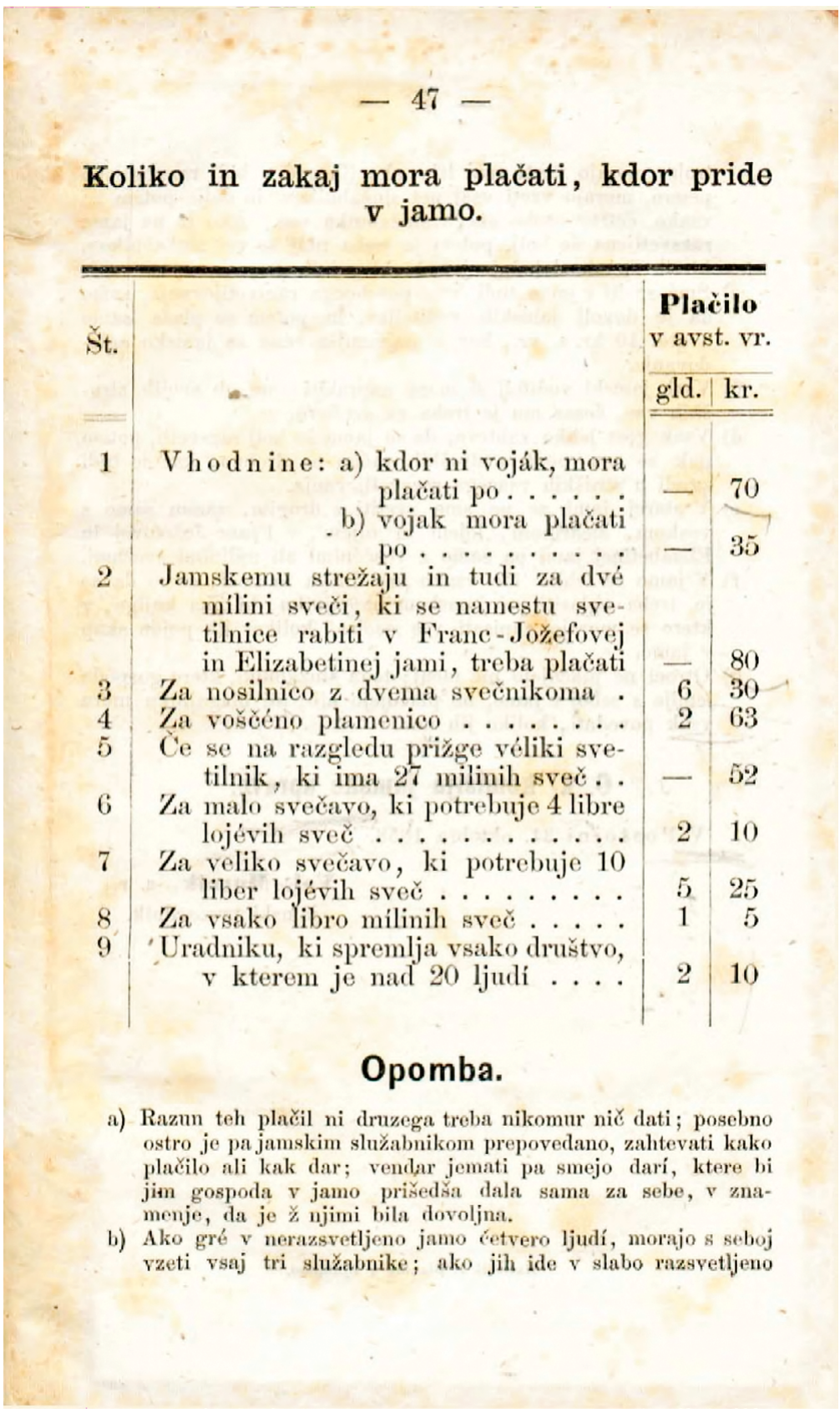

Slika 9.r: Cenik za vstopnico, vodenje in razsvetljavo v Posotojnski jami po Costovem vodniku iz leta 1863 
Nov cenik je jamska komisija izdala leta 1858 (Costa 1863, 47) ${ }^{3}$ : vstopnica za $\mathrm{v}$ jamo je znašala $70 \mathrm{kr}$, vojaki so ponovno plačali polovično ceno, cena za vodnika je znašala $80 \mathrm{kr}$. (pred tem so za vodnika plačali $30 \mathrm{kr}$.). Ob plačilu jamskega vodnika ${ }^{4}$ sta obiskovalcu pripadali dve milni sveči, vsaka nadaljnja libra (funt) ${ }^{5}$ milnih sveč pa je znesla 1,50 gld. Še naprej so ponujali več vrst razsvetljave: za nosilnico z dvema svečama so plačali 6,30 gld., za voščeno plamenico 2,63 gld., za manjšo razsvetljavo 2,10 gld., za večjo pa 5,25 gld. (slika 9.1). Pravilnik je za obisk jame določal obvezno spremstvo vodnika. Konec 6o-ih let je bila tarifa poenotena tudi za otroke (ki so prej plačevali polovično ceno) in služinčad (prej brezplačno). Za posebno razsvetljavo so bili na razpolago svetilničarji, ki so ravno tako pospremili obiskovalce. Nekateri vodiči so objavili tudi informacije o številu jamskih vodnikov, ki so spremljali skupine: dva vodnika sta spremljala skupino od enega do štirih turistov, če je bilo obiskovalcev več kot štiri, je bilo potrebno plačati še enega (Edeles 1869, 12-3 Baedeker 1876, 341; Costa 1863, 47).

\section{Tabela 9.ı: Cene za vstopnico in vodenje po Postojnski jami}

\begin{tabular}{cccc} 
Leto & $\begin{array}{c}\text { Vstopnica za civiliste } \\
\text { v goldinarjih in krajcarjih }\end{array}$ & $\begin{array}{c}\text { Vstopnica za vojake } \\
\text { v goldinarjih in krajcarjih }\end{array}$ & $\begin{array}{c}\text { Vodenje v goldinarjih } \\
\text { in krajcarjih }\end{array}$ \\
\hline 1824 & 24 & 12 & 12 \\
\hline 1834 & 30 & 15 & - \\
\hline 1852 & 30 & 35 & 30 \\
\hline 1858 & 70 & & 80 \\
\hline
\end{tabular}

Vir: glej besedilo.

Do druge polovice 19. stoletja je bilo jamo mogoče obiskati kadarkoli podnevi in ponoči (Costa 1863, 48), vendar je bil obisk vsaj od leta 1869 omejen na dva dnevna termina (Edeles 1869, 11). Če ponovno strnemo cene za jamskega vodnika, smo priča velikemu poskoku v ceni, zlasti po letu 1857: na začetku 19. stoletja je bil vodnik plačan $12 \mathrm{kr}$., leta 1852 30 kr. (Savnik 1960, 103) in $185880 \mathrm{kr}$. (Costa 1863, 47) (tabela 9.1). Temu naj bi botrovali visoki stroški, ki jih je imela jamska komisija ob pripravi veličastnega sprejema cesarskega para, ki se je leta $1857 \mathrm{z}$ vlakom pripeljal

3 Murrayevi (1871) in Baedekerjevi (1876) vodniki so v 70 -ih letih navajali enake tarife.

4 Prva znana pravila za jamske vodnike so bila izdana leta 1859. Izplačilo so dobili od dnevnega blagajnika, Shaw in Čuk 2015, 229.

5 Ena libra je 300 do $500 \mathrm{~g}$. 
v Postojno. Naslednje leto so zvišali vse tarife (Savnik 1960, 103). Po uvedbi nove valute, krone (Krone) in vinarja (Heller), v letu 1892 so ponekod še naprej veljale cene $\mathrm{v}$ stari valuti, na začetku novega stoletja pa so bile že določene v kronah. Lokalni časopis Notranjec je leta 1906 objavil cenik in urnik obiskov. Takrat je bila jama odprta celo leto, pozimi je bil obisk mogoč enkrat dnevno (ob 11. uri), medtem ko je bil med 1. marcem in 31 . oktobrom mogoč dvakrat dnevno (ob 11. uri in ob 15.30). Cena za vstopnico je znašala 5 kron $(2,5$ gld.), ob nedeljah pa 3 krone $(1,5$ gld.) na osebo (slika 9.2).

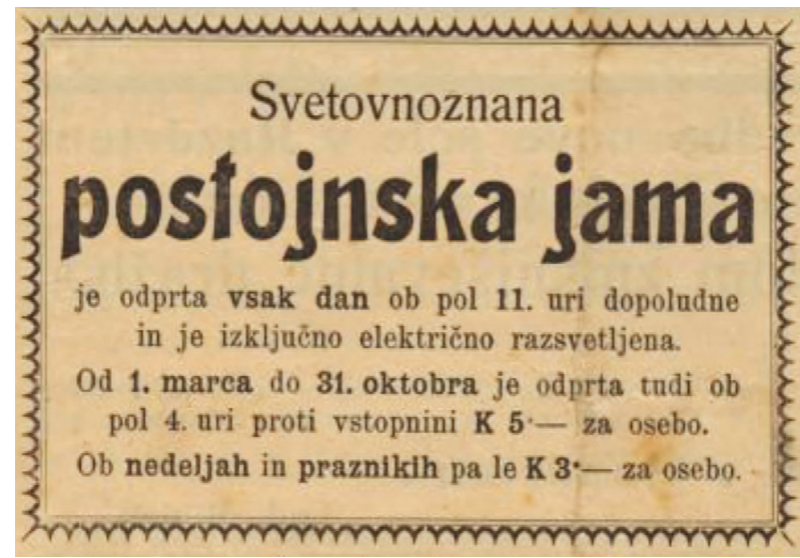

Slika 9.2: Oglas za Postojnsko jamo v lokalnem časopisu Notranjec, II. 8. 1906

Primer Postojnske jame kaže na relativno zgodnjo ureditev turistične ponudbe $\mathrm{z}$ regulacijo cen za ponujene storitve. Glede na to, da so bili z odprtjem jame za turiste in ustanovitvijo jamske komisije nekateri domačini $\mathrm{v}$ jami zaposleni kot vodniki, smo poskusili ovrednotili pomen in vlogo te dejavnosti oz. dohodka, ki je iz nje izhajal. Primerjali smo cenike za plačilo vodnika s povprečnimi cenami za kruh in meso v Ljubljani v enakem obdobju (tabela 9.2). ${ }^{6}$ Okrog leta 1834 je bil vodnik plačan 12 kr., kar pomeni, da si je glede na objavljene cene živil z enim vodenjem lahko kupil skoraj tri kilograme kruha. Od leta 1858 je bila vodniška tarifa 80 kr. Istega leta je

6 Glede na razpoložljive podatke smo naredili primerjavo z Ljubljano, ki pa je bila večje urbano središče na regionalnem nivoju (Kranjska) in so bile cene živil nedvomno višje kot v Postojni, ki je status mesta dobila šele leta 1909. Cene za živila je mesečno objavljal okrajni urad, navedene pa so bile tudi sestavine kruha. Tako je bil kilogram kruha narejen iz $3 / 4$ ržene in $1 / 4$ pšenične moke. 
bila v Ljubljani cena za funt mesa $12,5 \mathrm{kr} .(22,3 \mathrm{kr}$. za kg), kar pomeni, da si je vodnik $z$ enim vodenjem lahko privoščil dobre 3 kilograme mesa.

Tabela 9.2: Cenik za kruh in govedino v Ljubljani, prva polovica 19. stoletja

\begin{tabular}{ccc} 
Leto & Cena za kilogram kruha $(\mathrm{kr})$. & $\begin{array}{c}\text { Cena za funt govedine } \\
(\mathrm{kr} .)\end{array}$ \\
1820 & 3,4 & 6,0 \\
\hline 1830 & 4,4 & 5,6 \\
\hline 1840 & 4,7 & 7,7 \\
\hline 1850 & 5,5 & 9,8 \\
\hline
\end{tabular}

Vir: Melik 1981, 28-32. Cene so v goldinarjih in krajcarjih konvencijske valute (Conventionsmünze), ki je bilav uporabi do leta 1858 .

Poleg primerjave s cenami živil smo poskusili določiti relevantnost zaslužka $\mathrm{z}$ vodenjem $\mathrm{v}$ primerjavi s številom obiskovalcev. $\mathrm{Z}$ največ podatki o cenah razpolagamo za Postojnsko jamo, kjer je na tej podlagi mogoče vsaj v grobem oceniti letni dohodek od vodenja. Ker je en vodnik navadno vodil skupino od enega do štirih obiskovalcev (na ta način so si delili stroške, kar so jim svetovali tudi turistični vodiči), znano skupno število obiskovalcev razpolovimo in s tem pridobimo oceno števila vodenih obiskov. Vsak tak obisk je poleg vstopnice zahteval tudi plačilo vodnika, kar je stalo 80 krajcarjev, tako da je mogoče oceniti skupni letni dohodek od vodenj. Ob popisu prebivalstva leta 1869 je v Postojni živel 1.701 prebivalec (od tega 836 moških in 865 žensk) v 199-ih gospodinjstvih (Bevölkerung 1872). Tega leta je jamo obiskalo 3.927 turistov, kar pomeni, da je skupni letni dohodek od vodenj ocenjen na $157.080 \mathrm{kr}$. Da bi si laže predstavljali, koliko je to pomenilo za lokalne prebivalce, je mogoče skupni navedeni znesek deliti s takratnim številom postojnskih gospodinjstev. Rezultat tako izpeljanega izračuna nam predstavlja oceno povprečnega letnega dohodka od vodenj v jami, če bi bila $\mathrm{v}$ to dejavnost vključena vsa tamkajšnja gospodinjstva, to pa je $789,35 \mathrm{kr}$. za leto 1869 .

Po enakem ključu izračunamo še dohodek za leto 1880 , ko je $\mathrm{v}$ Postojni prebivalo 1.621 prebivalcev (773 moških in 848 žensk; Special-OrtsRepertorium 1884). Takrat je jamo obiskalo 4.547 turistov, kar je zneslo

$7 \quad$ Kljub temu, da je kmečko prebivalstvo, ki se je vključevalo v turistični sektor, te izdelke pridelovalo doma, je bila primerjava s cenami narejena zato, da na konkretnem primeru pokaže, koliko si je posameznik lahko privoščil za plačilo, ki ga je prejemal ob vodenju. 
181,88o kr. skupnega letnega dohodka od vodenj. Če navedeni znesek delimo s številom gospodinjstev (225), ponovno ob upoštevanju, da so bila v to dejavnost vključena vsa, je bil povprečni letni dohodek od vodenj po jami za vodnika 808,36 kr. (tabela 9.3).

Če v primerjavo vzamemo še povprečni letni dohodek stalnega delavca v Idrijskem rudniku iz leta 1891, ko je ta znašal 21.200 krajcarjev (212 goldinarjev; Kmetijske, 1. 1. 1892, 4), je mogoče oceniti, da je dohodek od vodenja $\mathrm{v}$ jami (kljub desetletnemu zamiku) povprečnemu postojnskemu gospodinjstvu predstavljal le 3,72 \% letnega dohodka delavca za leto 1869 in $3,81 \%$ letnega dohodka delavca za leto 188 o.

Ob upoštevanju, da vsako gospodinjstvo ni bilo vključeno $\mathrm{v}$ ta proces in se torej ni vsaj en član gospodinjstva ukvarjal $\mathrm{z}$ vodenjem ter da so bile skupine turistov lahko tudi manjše, kar je pomenilo vključevanje večjega števila vodnikov, so zgornje ocene le površne. $\mathrm{V}$ kolikor jih vzamemo $\mathrm{v}$ poštev, ugotovimo, da je vodnik z zaslužkom vodenja lahko preživel le mesec ali dva. Če se pri tem vrnemo na omembo, da so bili v Postojnski jami tudi stalno zaposleni vodniki (vsaj omenjeni Čeč, Šibenik in Berne), glede na višino zaslužka ne presenečajo njihove pritožbe o nezadostnosti zaslužka in zahteve po dosmrtnem monopolu nad vodniško službo.

\section{Tabela 9.3: Dohodek iz vodenja na gospodinjstvo Postojne leta I869 in I880}

\begin{tabular}{cccc} 
Leto & $\begin{array}{c}\text { Število gospodinjstev } \\
\text { v Postojni }\end{array}$ & Število obiskovalcev v jami & $\begin{array}{c}\text { Letni dohodek } \\
\text { na gospodinjstvo (ocenjena } \\
\text { povprečna vrednost v kr.) }\end{array}$ \\
\hline 1869 & 199 & 3.927 & 789,35 \\
\hline 1880 & 225 & 4.547 & 808,36 \\
\hline
\end{tabular}

Vir: glej besedilo.

Prikazana primerjava tarif za vodnika s cenami za živila, plačami, številom obiskovalcev in prebivalcev ne prinaša zanesljivih informacij o vlogi tega vira dohodka za kmečko prebivalstvo, ampak nam daje le približne ocene. Ne razpolagamo namreč s podrobnejšimi informacijami o socialnem statusu vodnikov, čeprav se že v predindustrijski dobi omenja, da gre večinoma za lokalne kmete iz okolice. V primeru Postojnske jame, ki je bila turistično dobro organizirana, lahko vidimo, da so bili nekateri vodniki redno zaposleni. O tem, da zaslužek rednega oz. poklicnega vodnika ni bil dober, pričajo tudi omenjene pritožbe. S podrobnejšimi podatki o vklju- 
čenosti domačinov v dejavnost, o pogostosti vodenja stalnih vodnikov, ki bi nam olajšali izračun, ne razpolagamo.

\subsection{Jame Škocjan, Vilenica in Divača}

Če je Postojnska jama kmalu prišla v državno last, pa je lastništvo drugih kraških jam ostalo na lokalnem nivoju. Kot je bilo že povedano, je bila druga jama, ki je v 19. stoletju beležila uspešni turistični razvoj, Škocjanska. Množičnejši obisk jamskega podzemlja je omogočila izgradnja stopnic leta 1823 (Müller 2013, 30). Na primeru Škocjanskih jam lahko od druge polovice stoletja tudi sledimo aktivni angažiranosti okoliških kmetov pri raziskovanju podzemlja in urejanju turistične infrastrukture. Domačini so, zlasti z jamarskim odsekom primorske sekcije Nemško-avstrijskega planinskega društva iz Trsta (Deutschen und Österreichischen Alpenverein, Section Küstenland - Abtheilung für Grottenforschung), ki je leta 1884 od občine Naklo prevzelo jame $\mathrm{v}$ najem, sodelovali pri raziskavah in odkrivanju še nepoznanih delov jam. Ko je jamarski odsek prevzel najem, se je namreč začela intenzivna faza raziskav, v katero so bili aktivno vključeni domačini, ki so okolico dobro poznali. To vlogo so jim pripoznali tudi ugledni člani planinskega društva, ki so podzemlje raziskovali »s pomočjo pridnih delavcev in sodrugov naših jamskih voženj, Jurija Cerkvenika, Pavla Antončiča ter Jožeta Cerkvenika«; bili so označeni kot izredno dobri poznavalci podzemlja, ki so bili vključeni v najzahtevnejše raziskovalne ekspedicije (Müller 2013, 39; Müller 1887, 9).

Zakupna pogodba je bila sklenjena $7.12 .1884^{8}$ med posebno svetovalno skupino županstva (davčna občina Naklo, župan Rajmon Mahorčič), ki so jo sestavljali Jožefo Cerkvenik (Vncek) kot vodja skupine in člani Ivan Berkovc (Rakič), Jožef Mahorčič, Ignac Gombač, Jože Cerkvenik (Kosljevec) ter Jožef Antončič (Preloseč), in člani primorske sekcije Nemško-avstrijskega planinskega društva P. A. Pazze, Carl baron von Czoernig in P. Pignoli. Pogodba o zakupu je bila sklenjena in podpisana med predstavniki davčne občine Naklo ter planinskega društva. Pogodba je za datum začetka najema določila 1. 5. 1885 in je bila sklenjena za dobo petih let. Planinsko društ-

$8 \quad$ Že februarja istega leta so potekala pogajanja oz. sestanek med županstvom Škocjana (Naklega) in primorsko sekcijo Nemško-avstrijskega planinskega društva o bodoči ureditvi odnosov glede uporabe in raziskav jam. Prisotni so bili tudi lastniki vhodov v jame. Predsedoval je Jožef Cerkvenik, prisotni so bili solastniki zemljišč: Janez Bukovec, Jožef Cerkvenik iz Naklega, Jožef Mahorčič in vodja protokola Franc Remec. V pogodbi oz. protokolu je bilo sklenjeno, da lahko društvo na območju njihovih parcel gradi nove poti, odpira nove vhode, raziskuje itd., Puc 2015, 33. 
vo je za najem plačevalo letni tribut v višini 10 gld. ${ }^{9}$ Društvo si je prizadevalo, da bi pridobilo čim več sponzorskih sredstev za raziskave, predvsem od svojih premožnih članov, baron Czoernig je celo ustanovil sklad za urejanje poti, Pazze plačal stroške za ureditev Pazzejeve poti (Velika dolina), gospa Oblasser pa financirala ureditev Oblasserjevega razgledišča (Miklov skedenj) (Pazze 1893, 165-6; Puc 2015, 34-7). Za primerjavo: v Postojni so si nekateri, predvsem podjetni hotelir Progler, prizadevali, da bi jamo dali $\mathrm{v}$ zakup zasebnikom. Med ponudniki za zakup je bila tudi družba Južna železnica, leta 1883 pa je ponudbo za 20 -letni najem dal neimenovani konzorcij. Ponujena letna najemnina je bila 2.500 gld., kar je neprimerno več, kot je bilo sklenjeno med Naklim in planinskim društvom. Jamska komisija je zasebnikov predlog zakupa jame zavrnila tako $\mathrm{z}$ vidika varovanja in ohranitve jamskega podzemlja (nenadzorovano trženje, prirejanje veselic, lomljenje in uničevanje kapnikov, preveč dima in razsvetljave s svečami) kot zaradi prenizke ponujene najemnine, saj naj slednja ne bi »dosegla niti polovice dotedanjih letnih dohodkov" (Savnik 1960, 109; Kranjc 2003, 278). Postojnski turizem je bil v 8o-ih letih že precej uveljavljen in turistična destinacija je tedaj beležila povprečno 5.600 obiskovalcev letno (Kavrečič 2017, 313). Čeprav za Škocjanske jame ne razpolagamo z natančnimi podatki o številu obiskovalcev (uničena vpisna knjiga), je ocenjeno, da je sredi stoletja jamo obiskalo okrog 150 turistov letno, torej bistveno manj kot v Postojnski jami. Ob prevzemu upravljanja s strani nemško-avstrijskega planinskega društva je slednje z letom 1901 pričelo voditi statistiko turističnega obiska. Med letoma 1901 in 1913 je bilo na letni ravni med 2.00o in 3.000 obiskovalcev (Kavrečič 2015a, 554; 558).

S pogodbo se je planinsko društvo zavezalo, da bo po svojih najboljših močeh skrbelo za ureditev poti in dostopa $\mathrm{v}$ jamo ter da bo slednjo $\mathrm{v}$ najkrajšem času odprlo za širšo javnost (Pazze 1893, 166). To dejanje jasno kaže, da so z jamo upravljali domačini iz okolice, kar pomeni, da je vsaj po zemljiški odvezi območje prešlo v upravljanje vaške skupnosti. Slednja je v tem primeru izkazala interes za izkoriščanje oz. trženje naravnih virov z namenom pridobivanja dodatnih virov dohodka iz neagrarne dejavnosti. Podoben proces je potekal tudi v jamah Vilenica in Divača.

$S$ pričetkom najema je jamarski odsek planinskega društva pričel z urejanjem turističnih poti, gradnjo mostov, vodenimi ogledi ter uvedel vstopnino (Müller 1887, 9-10; Pazze 1893, 207-12; Shaw 2008, 51-2). Jamarski odsek je kmalu po začetku zakupa izdal Razglas za Škocjanske jame 


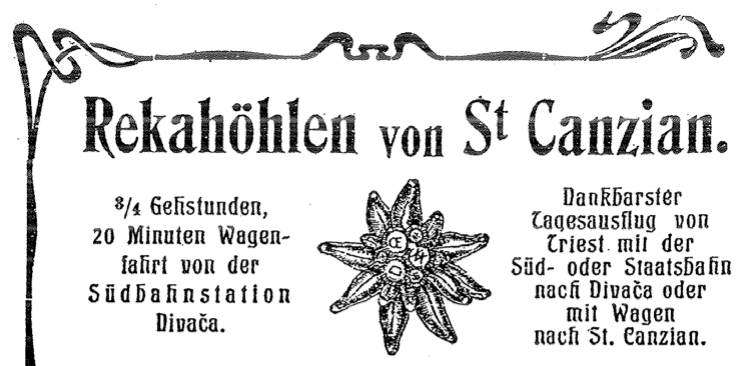

Diese können in jeder Jahreszeit bei Tug und bei Nacht besucht werden, aber nur mit autorisierten Führern, die im Gasthaus Gombač in St. Canzian zu finden sind, allwo die Eintrittskurten behoben werden.

\section{TARIF}

Eintrittsgebühro: 60 Heller pro Person.

\section{Tabellarischer Fïhrem-Tarif :}

\begin{tabular}{|c|c|c|c|c|}
\hline \multirow[b]{2}{*}{$\begin{array}{l}\text { Erste Stunde: } \\
\text { Zweite Stunde: }\end{array}$} & \multicolumn{4}{|c|}{ Mit Einem Fübrer: } \\
\hline & $\begin{array}{l}\text { Eine Person: } \\
80 \text { Heller } \\
40 \rightarrow\end{array}$ & $\begin{array}{l}\text { Z wei: } \\
80 \text { Heller } \\
40 \text { ? }\end{array}$ & $\begin{array}{c}\text { Drei: } \\
80 \mathrm{Heller} \\
60 \stackrel{ }{ }\end{array}$ & $\begin{array}{l}\text { Vier: } \\
80 \text { Heller } \\
80 ?\end{array}$ \\
\hline \multirow[b]{2}{*}{$\begin{array}{l}\text { Erste Stunde: } \\
\text { Zweite Stunde: }\end{array}$} & \multicolumn{4}{|c|}{ Mit Zwei Führern: } \\
\hline & $\begin{array}{c}\text { Fünf Pers.: } \\
\text { Kr. } 1.60 \\
>\quad 1.20\end{array}$ & $\begin{array}{l}\text { Sechs: } \\
\text { Kr. } 1.60 \\
>\quad 1.20\end{array}$ & $\begin{array}{c}\text { Sieben: } \\
\text { Kr. } 1.60 \\
>\quad 1.40\end{array}$ & $\begin{array}{c}\text { Acht: } \\
\text { Kr. } 1.60 \\
>\quad 1.60\end{array}$ \\
\hline & \multicolumn{4}{|c|}{ Mit Drei Führern: } \\
\hline Erste Stu & $\begin{array}{c}\text { Nenn Pers.: } \\
\text { Kr. } 2.40\end{array}$ & $\begin{array}{l}\text { Zehn: } \\
\text { Kr. 2.40 }\end{array}$ & $\begin{array}{c}\text { Elf: } \\
\text { Kr. } 2.40\end{array}$ & $\begin{array}{l}\text { Zwölf: } \\
\text { Kr. } 2.40\end{array}$ \\
\hline
\end{tabular}

Zweite Stunde: $|>2 .-|>2 .-|>2.20|>2.40$

Bei mehr Personen, für je eine bis vier Personen je ein Führer mehr, mit entsprechender Erhöhung des Führer-Lohnes nach vorstehender Skala.

Jede folgende Stunde wie die zweite. Die angegänzte Stunde wird für voll gerechnet.

Für je 1 bis 4 Personen ist ein Führer notwendig.

Belleuchtung für 1 bis 4 Besucher. Für den kleinen Rundgang, der 2-3 Stunden dauert, genügen . 1 halbe Pechfackel . . . . . . à Kr. 1.und 1 Kerze . . . . . . . . . . $\cdot .^{*}>-.20$

Für den grösseren Rundgang, der 3 bis 4 Stunden und auch länger dauern kann, braucht man:

1 grosse Pechfackel . . . . . . à Kr. 2.-

u. je 1 Kerze pro Besucher u. Führer > -.20 p. St.

Empfehlenswert, aber nicht absolut notwendig sind für den kleinen und grösseren Runigang:

2 od. 3 kleine Zinkfackeln . à Kr. 1.20 pro Stück Brenndauer 6 Minuten, Leuchtkraft 550 Kerzen)

5 bis 10 Meter Magnesiumdraht à Kr. -.20 pro Meter.

Für die neuentdeckte Lutteroth-Grotte, die schöne Tropfsteinbildungen enthält und vor deren Eingang die Pechfackeln ausgelöscht werden müssen, braucht jeder Besucher und Führer eine Kerze (à 20 Heller pro Stück) und stehen Magnesiumlampen (3 Kr. per Stunde) zur Verfügung.

$=$ Für grössere Beleuchtungen besteht ein eigener Tarif. $=$ Im orston Sonntag im Joni findeb ein grosses Grottentest stath gogen Bintritt ron Kr. 128, ohne woitore Anslagen.

Der Husschuss der Sektion Küstenland 
(Kundmachung, betreffend die Rekahöhlen von St. Canzian), ki je določil cenik za vstopnino in druge storitve. Vstopnica je stala $30 \mathrm{kr}$., enourno vodenje pa $20 \mathrm{kr}$. po osebi. Člani nemško-avstrijskega planinskega društva so bili oproščeni plačila vstopnine. $V$ primeru večjega števila obiskovalcev so si trije lahko delili enega vodnika ${ }^{10}$ in ga plačali $10 \mathrm{kr}$. po osebi. Za eno svečo so obiskovalci plačali 1o kr. (Illustirter Führer 1897, 91; Müller 1887, 108; Pazze 1893, 188). Vstopnico so obiskovalci kupili v Gombačevem gostišču v Matavunu "Pri Škocjanskih jamah" (Zu den St. Canzianer-Grotten), kjer so pridobili tudi informacije o cenah v treh jezikih (der Tarif für Führer und Beleuchtung in 3 Sprachen, deutsch, slavisch [slovenščini] und italienisch). Informacije o vodnikih pridobimo v nekaterih turističnih vodičih. Müllerjev vodič navaja imena naslednjih vodnikov, lokalnih prebivalcev bližnje vasi Matavun: Jože Antončič, Miha Gombač, Luka Gombač, Jože Cerkvenik (oče), Pavel Antončič, Juri Cerkvenik, Jože Cerkvenik. Z izjemo Jožeta Cerkvenika in Pavla Antončiča so vsi navedeni vodniki govorili vsaj osnovno italijanščino. Jože Antončič je govoril tudi malo nemško. V vodiču so omenjeni tudi drugi vodniki iz vasi Matavun in Škocjan, ki pa so govorilil le slovensko (Müller 1887, 9). Kljub temu, da je bilo tudi v tem primeru aktivno sodelovanje domačinov očitno, podrobnejših informacij, kot na primer podatkov o višini plačila, ki so ga morebiti prejeli ob raziskovalnih odpravah $\mathrm{v}$ jame, ter pogostosti vodenja, v omenjeni literaturi ne dobimo.

Cene za turistične storitve so bile neprimerno nižje kot tiste $\mathrm{v}$ Postojnski jami. Pri tem je potrebno izpostaviti, da so bile v tem obdobju na območju Škocjanskih jam v ospredju raziskovalne ekspedicije planinskega društva. Urejanje turistične dostopnosti v jamah je bilo precej zahtevno, saj so sočasno potekala odkrivanja novih delov podzemlja. Postojnska jama je bila $\mathrm{v}$ tem pogledu nedvomno $\mathrm{v}$ prednosti, saj je urejanje podzemlja za turistične obiskovalce potekalo že od začetka stoletja. Sicer pa so se, podobno kot v Postojnski jami, cene za turistične storitve spreminjale. Slika 9.3 prikazuje cenik za vstopnino, ki je leta 1907 znašala 60 vinarjev, ter za najem vodnika, kjer se je cena spreminjala glede na dolžino obiska in število obiskovalcev.

V turističnih vodičih poleg zgornjih dveh najdemo tudi kratke omembe jame Vilenica pri Lokvi. Murrayev vodič poda informacije o dostopu in možnostih obiska. Navedena je bila lokacija lepe jame le 10 milj od Trsta. Obiskovalec je ključe dobil pri gostilničarju Muhi (Mukow), kjer sta se hra-

10 Vodniški red za gorske in jamske vodnike Primorja je bil izdan 2. 8. 1884, Pazze $1893,153-8$. 
nila ključ in vpisna knjiga gostov (uvedena leta 1821). Cena za obisk je bila $15 \mathrm{kr}$. na osebo in po Murrayevem mnenju je za obisk zadostovala ena ura (Murray 1871, 458). Sicer je Murrayev edini vodič, ki je jamo sploh omenjal. Če je v tej izdaji namenil le nekaj informacij o jami, je bil v starejši (iz leta 1837) precej kritičen. Omenja jamo v bližini Lokve, vasi, kjer je obiskovalec lahko najel vodnika in razsvetljavo, a jo označi kot »far more inferior cavern« in poleg tega težko dostopno (spust je strm, na nekaterih delih težak, celo navaren) (Murray 1837, 294). Ta opis se precej razlikuje od Fortisovega, ki je nastal le šestdeset let prej. Jami Vilenica ni namenil prijaznih besed niti baron William Monson leta 1817, ki si je zaradi prevarantskih domačinov ni ogledal. Po daljšem iskanju jame so domačini za obisk zahtevali plačilo petih forintov (goldinarjev), tarifo, ki je bila po njihovih besedah določena z zakonom. Potem ko je skupaj s sopotniki zahteval ogled uradnega cenika, so domačini spustili ceno za polovico, cenika pa niso pokazali, češ da je shranjen v Trstu. Plačilo za vodenje pa so celo zahtevali vnaprej (Shaw 2008, 119). Dogodek, ki se je pripetil Monsonu, kaže na to, da je poleg »uradne« dejavnosti sočasno potekala tudi manj legalna. V primeru Monsona domačinom prevara ni uspela, saj jame ni obiskal. Vstopnina za skupino obiskovalcev je leta 1809 res znašala 2 goldinarja (Agapito 1823, 22), tekom stoletja pa se je precej nižala.

V Vilenici so vstopnino uvedli leta 1633 , vhod pa so lastniki zaprli leta 1809. Takrat so bili vsi dohodki jame preneseni na lokavsko cerkev (Agapito $1823,22)$. Domačini so bili vključeni v urejanje jamskega podzemlja, saj so leta 1815 odkrili nove dele jame in uredili nove poti za obisk. ${ }^{\text {II }}$ Tekom stoletja je v sodelovanju s tamkajšnjo cerkvijo $\mathrm{z}$ jamo upravljala in jo tržila lokavska skupnost. Ključ in jamsko knjigo (vpisna knjiga) je vsaj od leta 1839 hranil lokavski gostilničar Muha, kjer so obiskovalci najeli tudi vodnika. Podjetni gostilničarji so nekaj časa jamo tudi upravljali, med člani družine sta bila tudi dva vodnika (Vencel in Viljem Muha) (Puc 200o, 31-2). Kljub pohvalam, ki so jih bili deležni jamski vodniki (Knowledgeable Guides, Ready to Accompany Us with the Necessary Lights, J. G. Kohl 1850) (Shaw 2008, 196), in slovesu, ki ga je imela Vilenica, se je tekom 19. stoletja obisk manjšal. Na to kaže tudi konstantno nižaje cen za turistične storitve. Če je vstopnina (sicer za skupino) še na začetku stoletja znašala 2 gld., je bila v 70ih letih le še 15 kr. V zapisih Virgila Ščeka iz časa, ko je služboval v lokavski kaplaniji, se pogosto omenja jama Vilenica, tako v povezavi z njeno slavno preteklostjo kot izvorom imena. Nekaj informacij je mogoče razbrati o do- 
hodkih od prodaje vstopnic in delitvi dobička z lokavsko cerkvijo ${ }^{12}$ na začetku 19. stoletja, podrobnejših informacij o jamskih vodnikih in vlogi domačinov pri ponudbi turističnih storitev pa avtor ni navedel (Šček 1937).

Kljub naporom jamske komisije italijanskega planinskega društva (Società Alpina delle Giulie - Commissione delle grotte), ki je z lokavsko skupnostjo (katastrsko občino) leta 1886 sklenila najemno pogodbo, je bila turistična dejavnost $\mathrm{v}$ zatonu. Jamska komisija je za lažji dostop pričela urejati turistične poti v jami, ponudbo razsvetljave in vodenja. Znani jamar in tajnik (kasnejši predsednik) omenjenega planinskega društva, Eugenio Boegan, je v svojem poročilu ${ }^{\mathrm{I} 3} \mathrm{o}$ urejanju jame predstavil njeno »slavno « zgodovino, jo celo opisal kot eno izmed najlepših, najbolj obiskanih, opisanih in opevanih jam v preteklosti, ki pa je ob odkritju drugega dela Postojnske jame, lažjemu dostopu v Škocjanske jame ter odkritju Divaške jame tonila v pozabo. Jama je bila sicer še naprej obiskana, kar dokazujejo tudi vpisi v knjigo gostov, čeprav je obisk ne glede na ureditev poti in razsvetljave proti koncu 19. stoletja upadal (Boegan 1897, 10-16; Kavrečič 2015a). Slabšemu obisku naj bi botrovala tudi slaba prometna povezava, saj je bila s koncem 18. stoletja državna cesta (Trst-Dunaj) speljana izven Lokve (Puc 2000, 27). ${ }^{\mathrm{I}}$ Slovenski časopis Edinost iz Trsta je prav tako poročal o slabem obisku: »Sredi jame je plešišče za veselice; te so se pa sedaj popolnoma opustile in zadnji čas jamo le malo kedo več obišče.» Slednje so pripisali predvsem slabemu upravljanju oz. najemnikom, ki so jo zanemarjali. Težava je bila torej $\mathrm{v}$ slabem upravljanju $\mathrm{z}$ jamo in nezadostni turistični ponudbi. Gregor Lanthieri in Anton Muha sta omenjena kot dobra upravljalca, ki sta precej vlagala $\mathrm{v}$ posodobitev infrastrukture (ureditev dostopa) in $\mathrm{z}$ organizacijo družabnih dogodkov uspela privabiti številne obiskovalce. Ob dobrem obisku jame pa se je polnila tudi blagajna lokalnih gostincev. Najemnik Anton Muha »je priredil tri veselice v jami s čarobno

$12 »$ Leta 1816 so tujci dali za obisk jame 99 goldinarjev, grof Adelmus Petazzi je dal 65 goldinarjev, skupaj 165 gold., leta 1817 so dali obiskovalci jame 71 gold., leta 1818 pa 41 gold «, Šček 1937, 79.

13 Poročilo o jami Vilenica, ki ga je na zasedanju društva predstavil E. Boegan, je bilo objavljeno tudi v obliki separata leta 1897.

14 Tudi trasa južne železnice ni potekala skozi Lokev, ampak skozi Divačo. Nekdaj na dobri prometni povezavi - poštna kočija - je bila $\mathrm{v} 18$. stoletju pot preusmerjena drugam in oddaljenost od divaške postaje naj bi botrovala tudi slabemu obisku. Vendar to zagotovo ne more biti edini utemeljeni razlog, saj so Škocjanske jame na približno enaki razdalji od Divače, kot je bila Vilenica, v tem primeru pa ta razdalja očitno ni vplivala na slabši obisk. Razloge za upad obiska je potrebno iskati tudi v samem upravljanju jame (glej Kavrečič 2015, 553). 
svečavo in vsaki krat jo bilo na tisoče obiskovalcev. Kar so pa drugi manj umni in skrbni ljudje to jamo v najem vzeli, zaspale so vse te veselice in jama se je zelo zanemarila" (Edinost, 13. 4. 1881, 2). Krivdo za to so pripisali predvsem nezainteresiranosti in preslabi podjetnosti lokavske občine, ki ni izkazovala pretiranega interesa za vlaganja $\mathrm{v}$ poti, popravilo stopnic in nudenje ustrezne ponudbe. Pisec $\mathrm{v}$ časopisu je bil mnenja, da bi lahko $\mathrm{z}$ ureditvijo krepko povišali ceno letnega najema, vendar je glede na to, da so domačini opustili vlaganja $\mathrm{v}$ to dejavnost, na mestu vprašanje, ali so se jim že pretekle naložbe sploh obrestovale.

V tem obdobju je bila v bližini odkrita nova jama, t. i. Divaška jama (Kronprinz Rudolf Grotto). Leta 1884 jo je odkril Gregor Žiberna skupaj s kmeti iz okolice Divače, Alojzom Obersnelom, Adalbertom Rebcem, Petrom Silo in Antonom Rešavrom (Edinost, 25. 6. 1884, 3; Puc 1999, 17). Kmalu je stekla ureditev za turistični obisk, ki jo je vodila divaška skupnost (občina). Z ureditvijo jame za obisk (poti, vodniki, razsvetljava) so jo pričeli tudi tržiti. Turisti so vstopnico lahko kupili v gostilni Obersnel v Divači (v bližini železniške postaje), kjer so dobili tudi vodnika. Znan obiskovalec jame je bil Sigmund Freud, ki ga je leta 1898 po njej vodil Gregor Žiberna. ${ }^{15}$ Kljub temu, da je slednjega Freud označil za posebneža, precej grobega, a sigurnega, dobrovoljnega in humornega, celo propadlega genija in nevrotika, mu je namenil bogato napitnino (several Gulden) (Shaw 2008, 54, 292-3). Leta 1886 je jamarska sekcija Avstrijskega turističnega kluba (Österreichischen Touristen-Klub) od občine Divača (pod davčno občino Naklo) vzela jamo v najem za obdobje desetih let (Edinost, 23. 3. 1887, 2). Tudi v tem primeru je lokalna skupnost jamo tržila in s tem pridobivala dodatne vire dohodka. Zaradi slabega gospodarjenja, počasnega urejanja poti, slabega obiska in nerednega plačevanja najemnine (pomanjkljiv nadzor s strani divaške skupnosti) se je pogodba leta 1890 predčasno prekinila. Tako kot v Vilenici in Škocjanskih jamah je tudi v tem primeru upravljanje prešlo na planinsko društvo, kajti leta 1904 jo je v zakup vzela tržaška podružnica Slovenskega planinskega društva (slika 9.4). Vstopnina je bila določena na 1 krono (o,5 gld.); plačilo za vodnika in razsvetljavo je zneslo 3 krone (1,5 gld.; Planinski vestnik 1909, 99). Med jamskimi vodniki zasledimo le nekaj imen: Gregor Žiberna, ki je govoril tudi tuje jezike in dejansko živel od vodniške službe, ter Anton Obersnel, Valentin Rešaver in Ignacij

15 Žiberna je bil vnet raziskovalec podzemlja, ki je sodeloval tudi s člani Nemškoavstrijskega planinskega društva. Hranil naj bi kjigo gostov, ki je bila kasneje uničena v požaru. 
$68-$ Št. 4. PLANINSKI VESTNIIK XI. -1905

zadnjem občnem zboru, nabirati prispevke $\mathrm{v}$ pokritje stroškov za nameravane naprave, ki so nujno potrebne.

Izvršujoč ta sklep, nabira Tržaška podružnica Slovenskega planinskega društva darila, za kar se je začela subskripcija.

Darila z imenikom darovalcev je poslati podpisani Tržašk podružnici Slovenskega planinskega društva, ki objavi v Planinskem Vestniku in $v$ drugih časopisih imena darovalcev.

Tržaška podružnica Slov. plan. društva.

202020202020202020202020202020202020202020202020

\section{DIVAŠKO VILENICO!}

Prekrasna „Divaška vilenica «, katere divota je še marsikomu neznana, je prišla $v$ posest Slovenskega planinskega društva., oziroma njegove Tržaške podružnice. S tem je spravilo »Slovensko planinsko društvo a prvi podzemeljski dom v svoj delokrog, kar bode gotovo varadostilo slehernega rodoljuba.

In kako proslaviti ta važni dogodek?

Tržaška podružnica je sklenila, prirediti $\mathbf{v}$ nedeljo, dne 14. maja t. I., velik slavnostni izlet $v$ Divačo, združen $s$ posetom jame in $z$ veliko ljudsko veselico na planem, da proslavi tako na dostojen način ta pomembni dogodek.

Iz Trsta odide poseben vlak z znižano voznino ob osmih zjutraj. Povratek ob devetih zvečer.

Pri popoldanski veliki ljudski veselici, ki se bo vršila na planem, bodo sodelovala razna društva.

$\mathrm{Na}$ ta slavnostni izlet in obisk jame ter na veselico se usojamo najvljudneje vabiti cenjeno osrednje društvo in vse podružnice.

Priglasiti se je najkasneje do dne 1. maja t. I. na naslov: Tržaška podružnica Slovenskega planinskega društva, Trst, Via Chiozza 8.

Odbor Tržaške podružnice.

202020202020202020202020202020202020202020202020

\section{PRISTOJBINE V DIVAŠKI VILENICI.}

Pristojbina za enega vodnika in razsvetljavo znaša ne glede na število oseb $3 \mathrm{~K}$. Vstopnine plača vsaka oseba $1 \mathrm{~K}$. Clani "Slov. plan. društva. plačajo proti izkaznici polovico. Za večje družbe, društva, zavode, šole proti poprejšnji priglasitvi pri odboru Tržaške podružnice vstopnina po dogovoru.

Odbor Tržaške podružnice.

Urednik Anton mnut. - lzdaja in zalaga „,Slov. plan. društvo“. - Tisk J. Blasnikov v Ljubljani.

Slika 9.4: Oglas za Divaško jamo v Planinskem vestniku (časopis Slovenskega planinskega društva) 1905,68

Čelik (Puc 1999, 19, 23; Žiberna 1981, 148-9). ${ }^{16}$ Razlog za tako »skromno« ponudbo vodnikov je bila neangažiranost domačinov pri tej dejavnosti. Domnevni razlog za nezainteresiranost drugih domačinov je povezan s pomanjkljivim znanjem tujih jezikov. Matjaž Puc, avtor številnih publikacij o kraških jamah, je sklepal, da so bili za Divačane drugi viri do-

16 Leta 1897 sta le prva dva omenjena kot sposobna vodnika, Puc 1999, 23. 
hodkov (iz agrarne in neagrarnih dejavnosti) pomembnejši ali da preprosto niso bili zainteresirani za aktivno sodelovanje pri tej dejavnosti (Puc 1999, 25). Zakaj se torej domačini, z izjemo Žiberne, niso zanimali za vključevanje v ponudbo rastočega jamskega turizma? Razlogov je lahko več in niso nujno povezani z nepoznavanjem tujih jezikov. Eden je lahko bila nevarnost samega dela (na primer nesreče, ki so se dogajale tekom raziskav, tudi smrtne) ali finančno relativno skromen izkupiček. Težava je lahko bila tudi v neregulirani vodniški službi in nerednemu pobiranju vstopnine, ${ }^{17}$ kar lahko razberemo tudi iz korespondence nakelskega župana (Puc 1999, 23). Davčna občina Naklo je bila odgovorna tudi za upravljanje Škocjanskih jam, pri čemer je za razliko od jame v Divači precej uspešno prenesla upravljanje na zunanjega ponudnika, planinsko društvo. V primerjavi z Lokvijo (Vilenica) in Matavunom (Škocjan) je bilo odkritje jame relativno pozno, ${ }^{18}$ pri tem je bilo potrebno šele urediti dostop in varne poti, kar je morda tudi botrovalo domnevni nezainteresiranosti domačinov. V tem obdobju se je Divača razvijala v moderno prometno vozlišče, ki se je povezalo s prestolnico na Dunaju, osrednjim cesarskim pristaniščem v Trstu (južna železnica: 1857$)$ ter sedežem vojne mornarice v Pulju (istrska železnica: 1876), kar pomeni, da so druge neagrarne dejavnosti kmečkega prebivalstva najverjetneje predstavljale donosnejši posel.

\section{Sklep}

Jamski turizem velja za eno najstarejših turističnih dejavnosti na Slovenskem, saj je bil na območju Krasa prisoten že od zgodnjega novega veka. Posebna naravna privlačnost so podzemne jame, ki so že v preteklosti predstavljaje velik potencial za razvoj turistične atrakcije ter s tem odpirale možnosti novih virov zaslužka za lokalno kmečko prebivalstvo iz ne-

17 V primeru Divaške jame vodniška služba ni bila regulirana (pravilniki, ceniki); edini dve določeni tarifi sta bili vstopnina in vodenje. Nakelski župan je priporočil, da se za ogled (vstopnino) pobira 60 kr., $10 \mathrm{kr}$. za sveče in $10 \mathrm{kr}$. za magnezij. Plamenice niso bile dovoljene (Puc 1999, 23; Žiberna 1981, 149). Poleg tega so bili odnosi med Žiberno in lokalno oblastjo precej konfliktni. Žiberna, ki je odkril jamo, je sebe videl kot edina sposobnega jamskega vodnika. Imel je status nekakšnega »skrbnika in vodnika«, ki mu je za opravljeno delo plačevala uprava jame. Ker se mu skupnost ni na noben način oddolžila oz. mu poplačala za njegovo pomembno odkritje, so mu neuradno dovolili, da je postal glavni vodnik po jami. Težavni odnosi so se z imenovanjem novega župana še stopnjevali (Žiberna 1981, 148-9).

18 Ni sledu o ljudski ali drugi obliki religionznih praks, ki bi bile povezane z Divaško jamo in bi lahko kazale na poznavanje jame pred njenim uradnim odkritjem (glej tudi Hrobat Virloget 2015). 
agrarnega sektorja. Povedali smo, da težki pogoji za obdelovanje zemlje na Krasu in skromen pridelek niso zadoščali za preživetje. Ob tem so si morali podjetni in iznajdljivi domačini iskati še dohodke v drugih dejavnostih, kot na primer prevozništvu, kmečki trgovini in tihotapstvu (Panjek 2014, 2001). Poleg omenjenih so na tem območju ravno naravne privlačnosti predstavljale potencialni vir dodatnega zaslužka za domačine že v predmoderni dobi. Z razvojem moderne turistične dejavnosti pa je vpliv tega sektorja narasel. Pokazale so se potrebe po večji ponudbi nastanitvenih kapacitet, gostinskih storitev, vodniški službi in razsvetljavi, kar je bilo organizirano za namen razvijajoče se turistične industrije.

$\mathrm{V}$ prispevku sem poskusila ugotoviti, ali je podeželsko prebivalstvo iz okolice najprepoznavnejših kraških jam, dane možnosti tudi izkoristilo. Je turistična atrakcija vplivala na lokalno kmečko ekonomijo in v kolikšni meri je bila relevantna za domačine? Se je $\mathrm{v}$ primeru jamskega turizma lokalno prebivalstvo vključevalo $\mathrm{v}$ ta proces oz. ponudbo? Na slednje lahko nedvomno odgovorimo pritrdilno, saj so bili domačini tisti, ki so dobro poznali svojo okolico in dejansko edini, ki so lahko obiskovalce vodili po podzemlju. Vključevali so se torej predvsem kot jamski vodniki in svetilničarji, tekom 19. stoletja pa tudi za prodajo hrane gostilnam in hotelom ter kot prevozniki turistov. Ta dejavnost iz neagrarnega sektorja je predstavljala integracijo z zaslužkom iz primarnega sektorja, čeprav je težko izsledljiva. Na podlagi dostopnih virov ni bilo mogoče natančno kvantificirati dohodka, ki ga je imel vodnik, ali pa ovrednotiti njegov prispevek družinski blagajni, ker ni podatkov o pogostosti vodenja ali načinu in stopnji vključenosti lokalnega prebivalstva $\mathrm{v}$ ta proces. Okvirna ocena je bila narejena za Postojnsko jamo, kjer so se zaradi naraščajoče turistične popularnosti tekom celega 19. stoletja cene za ponujene storitve precej spreminjale in bile tudi redno objavljane. Vodniška dejavnost se je v nekaterih primerih celo profesionalizirala in je za nekaj posameznikov predstavljala tudi primarni poklic.

Kljub temu, da so predstavljeni izračuni le okvirni, pa dejstvo, da so se lokalne skupnosti vključevale v turistični proces s svojo ponudbo jamskega turizma, kaže, da je ta dejavnost imela določeno finančno težo. Vključevanje v turistično dejavnost je izrazitejše v drugi polovici 19. stoletja, ko so nekdanje posesti fevdalnih gospodov, kjer so se nahajale tudi jame, prešle v upravljanje vaških skupnosti. Tako se jim je ponudila priložnost za trženje jam v turistične namene, kar se je kot posebej učinkovito pokazalo na primeru Škocjanskih jam (res je tudi, da v primerjavi z drugimi jamami 
najemnina ni bila visoka). Sočasno so tu potekale raziskave in turistično urejanje poti ter ponudbe, kjer so bili $\mathrm{v}$ obeh primerih domačini aktivno vključeni. V jami Vilenica so nekateri drugi predstavljeni dejavniki vplivali na upad obiska, ki ga kljub vlaganju ni uspelo oživiti niti italijansko planinsko društvo (najem leta 1886). Proti koncu stoletja cena za vstopnino tudi konstantno pada. Tu smo bili priča obratnemu procesu. Če je več podatkov o domačinih - vodnikih iz predindustrijske dobe, se jih v tem obdobju, predvsem proti koncu stoletja, skorajda ne omenja več. Ravno tako se vedno redkeje pojavljajo $\mathrm{v}$ turističnih vodnikih. Po drugi strani pa narašča priljubljenost Divaške jame, ki se na začetku prejšnjega stoletja čedalje pogosteje pojavlja v tiskanih medijih (časopisi, turistični vodiči). ${ }^{19}$

Lahko zaključimo, da je bil turizem že pred moderno dobo, torej pred pojavom specializiranih storitev in ponudbe na trgu, ena izmed neagrarnih dejavnosti, ki so kmečkemu prebivalstvu pomagale polniti domačo blagajno. Kmetje iz vasi v bližini jam, ki so dobro poznali svojo okolico, so popotnikom nudili predvsem vodniške usluge in razsvetljavo po jamskem podzemlju. Tako so imeli koristi od jamskega turizma že v predindustrijski dobi ter $\mathrm{v}$ nekaterih primerih tudi $\mathrm{v}$ dobi modernizacije turistične ponudbe (poleg vodništva tudi prodaja pridelkov, prevozi), čeprav, kot je bilo pokazano, je imel turizem $v$ analiziranih primerih različno stopnjo učinka. $\mathrm{V}$ obeh obdobjih pa je omogočil integracijo kmečkega prihodka iz primarnega s tistim iz terciarnega sektorja.

\section{Viri in literatura}

Arhivski viri

ŽAL: Župnijski arhiv Lokev

Šček Virgil, Lokavske starine I in II, 1937.

AST, CF: Archivio di Stato di Trieste, Catasto Franceschino, Elaborati catastali S 5.17.20.21 - Distretto di Sesana.

\section{Objavljeni viri}

Bevölkerung und Viehstand der die Reichsrate Vertretenen Königreiche und Länder nach der Zählung vom 31. December 1869. Bearbeitet und herausgegeben von der K. K. Statistischen Central-Commission, VI. Heft, Wien, 1872 .

19 Pri tem igra vlogo tudi dejstvo, da je jamo v zakup vzelo ravno Slovensko planinsko društvo. 
Edinost: Edinost. Glasilo slovenskega političnega društva za Primorsko

Edinost, 13. 4. 1881, 1. 6, št. 15.

Edinost, 24. 5. 1884, 1. 9, št. 42.

Edinost, 25. 6. 1884, 1. 9, št. 51.

Edinost, 23. 3. 1887, 1. 12, št. 24.

Kmetijske: Kmetijske in rokodelske novice

Kmetijske, 1. 1. 1892, 1. 50, št. 1: Govor državnega poslanca g. dr. Ferjančiča, 3-4.

Notranjec

Notranjec, 11. 8. 1906, 1. II., št. 32.

Planinski vestnik: Planinski vestnik. Glasilo slovenskega planinskega društva Planinski vestnik, 1909, 1. 15, št. 5.

Special-Orts-Repertorium von Krain. Herausgegeben von der K. K. Statistischen

Central-Commission. / Obširen imenik krajev na Krajnskem. Na svitlo dan po C. Kr. statistični centralni komisiji, VI Krain, Wien, 1884.

\section{Literatura}

Agapito, G. 1823. Le grotte di Adlersberg, di S. Canciano, di Corniale e di S. Servolo, la miniera di mercurio d'Idria, il lago di Cirknitz, le terme di Monfalcone, antichità Romane d'Aquileja e Pola, ed altri notevoli oggeti nelle vicinanze di Trieste. Vienna: dalla tipografia di Antonio Strauss. Trieste: A spese di Paolo Schubart.

Baedeker, K. 1876. Südbaiern, Tirol und Salzburg, Steiermark, Kärnten, Krain und Küstenland. Handbuch für Reisende. Leipzig: Verlag von Karl Baedeker.

Boegan, E. 1897. La grotta di Corniale. Estratto dalla Rassegna bimestrale della »Società Alpina delle Giulie« a. II, št. ri 2, 3, 4, e 5. Trieste: Stabilimento Art. Tip. G. Caprin.

Costa, E. H. 1863. Postojnska jama. Ljubljana: Založil Janez Giontini.

Čeč, D. 2001. »Zakaj je Postojna hotela postati mesto?« Zgodovina za vse 8 (1): $36-51$.

Čuk, A. 2003. »Razvoj jamske železnice na primeru Postojnske jame.« Acta carsologica 32 (1): 225-42.

Edeles, E. 1869. Description of the Grotto at Adelsberg in Carniola. Trieste: printed by the Austrian Lloyd's. 
Habe, F. 1979. »Anton Globočnik, narodni buditelj in pionir jamskega turizma.« Loški razgledi 26 (1): 177-81.

Habe, F., in A. Kranjc. 1981. „Delež Slovencev v speleologiji.« Zbornik za zgodovino naravoslovja in tehnike 5-6: 13-93.

Hrobat Virloget, K. 2015. »Caves as entrances to the world beyond, from where fertility derives. The case of SW Slovenia.« Studia mitologica Slavica 18: $153-63$.

Illustrierter Führer durch Triest und Umgebungen: nebst Ausflügen nach Aquileja, Görz, Pola, Fiume, Abbazia und Venedig, durch Istrien, im Quarnero, auf der Pontebbabahn, nach dem Wörthersee, Klagenfurt und Ober-Krain. 1897. Wien, Pest, Leipzig: A. Hartleben's Verlag.

Kariž, S. 2008. »Od jamskih svetilničarjev do turističnih vodnikov.« Kras 88: $22-4$.

Kavrečič, P. 2007. "Parni stroj in turizem na Primorskem. Prometne povezave kot dejavnik turističnega razvoja na primeru Postojne in Portoroža do prve svetovne vojne.« Annales, Series historia et sociologia 17 (2): 315-36.

Kavrečič, P. 2015a. »Turistični razvoj jame Vilenica in Škocjanskih jam po poročanju planinskih društev in vodnikov v drugi polovici 19. stoletja.« Kronika, Iz zgodovine Krasa 63 (3): 547-60.

Kavrečič, P. 2015b. Turizem v Avstrijskem primorju. Zdravilišča, kopališča in kraške jame (1819-1914). Koper: Založba Univerze na Primorskem.

Kavrečič, P. 2015c. „Visiting the Karst Underground.« V Stone Narratives: Heritage, Mobility, Performance, uredili K. Hrobat Virloget, I. Weber, D. Fabjan in A. Preložnik, 65-76. Koper: Založba Univerze na Primorskem.

Kranjc, A. 2002. "Short History of Cave Tourism in Slovenia." V Use of Modern Technologies in the Development of Caves for Tourism, 4th International ISCA Congress, Postojna, 21st-27st October 2002, 55-60. Postojna: Postojnska jama, turizem.

Kranjc, A. 2003. "1883 - prelomno leto za Postojno.« V Sprehod skozi čas. Ob 12o-letnici Turističnega društva Postojna, uredili S. Šajn idr., 27-8. Postojna: Turistično društvo.

Lavallée, J. 1805. Travels in Istria and Dalmatia Drawn up from the Itinerary of L. F. Cassas. London: Richard Phillips.

Melik, V. 1981. »Ljubljanske cene kruha in mesa v predmarčni dobi.« Kronika, časopis za slovensko krajevno zgodovino 29 (1): 27-33. 
Müller, F. 1887. Führer in die Grotten un Höhlen von Sanct Canzian bei Triest und Notizrn über den Lauf der Reka. Mit heliographischen Ausichten und einem Situationsplan. Triest: Verlag der Section Küstenland.

Müller, F. 1890. Entdeckungsfahrten in den St Canazianer Höhler im Jahre 1890. Wien: Drück von Adolf Holzhausen.

Müller, F. 2013. Škocjanski jamski svet. Škocjan: Park Škocjanske jame.

Murray, J. 1837. A Handbook for Travellers in Southern Germany. London: John Murray and Son.

Murray, J. 1871. Handbook for Travellers in Southern Germany. 11th ed. London: John Murray.

Neuester praktischer Fremdenführer von Triest und Umgebung: mit Ausflügen nach Miramar, Opcina, Portorose, Sistiana, Duino, Grado, Aquileja, den Höhlen von Adelsberg, St. Canzian und der Kronprinz Rudolphsgrotte: mit Illustrationen und neustem Strassenplan. 7. Aufl. Around 1910. Triest: F. H. Schimpff.

Panjek, A. 2014. »Integrirana ruralna ekonomija v zahodnem slovenskem prostoru v zgodnjem novem veku." V Vizija raziskav slovenske gospodarske in družbene zgodovine, uredila D. Mihelič, 199-205. Ljubljana: Zgodovinski inštitut Milka Kosa ZRC SAZU.

Panjek, A. 2015. Kulturna krajina in okolje Krasa. O rabi naravnih virov $v$ novem veku. Koper: Založba Univerze na Primorskem.

Pazze, P. A. 1893. Chronik der Section Küstenland des deutschen und österreichischen Alpenvereins, 1873-1892. Fest-Publication zur Vollendung des XX. Vereinsjahres. Triest: Selbstverlag der Section Küstenland.

Pazze, P. A. 1907. Neuer kleiner Wegweiser für die Besucher der St. Kanzianer Grotten. S. Küstenland (Dr.: Meneghelli).

Postojinsko okrajno glavarstvo. 1889. Zemljepisni in zgodovinski opis. Spisali in izdali učitelji v okraji. Postojna: Založil in tiskal R. Šeber.

Puc, M. 1999. Divaška jama. Divača: Občina.

Puc, M. 200o. Vilenica, zgodovina in opis kraške jame. Sežana: Kulturni center Srečka Kosovela.

Puc, M. 2015. Škocjanske jame pri Divači: kronika raziskovanj in turističnega obiska. Škocjan: Park Škocjanske jame.

Savnik, R. 1958. »Iz zgodovine Postojnske jame.«Kronika 7 (3): 138-45.

Savnik, R. 1960. »Iz zgodovine Postojnske jame.« Kronika 8 (2): 99-101. 
Schaffenrath, A. 1834. Beschreibung der berühmten Grotte bei Adelsberg in Krain, nach allen ihren Verzweigungen, Ende und Klüsten; in Bezug auf Richtungen, Distanzen, Höhen und Sehenswerthe derselben, sammt einer vor dem Eintritte erwünschten Uebersicht, und einem die Eintrichtung und den P. T. Herren Grotten-Gast betreffenden Anhange: mit zwei lithographirten Zeichnungen. Ljubljana: I. A. v. Kleinmayr.

Seume, J. G. 2004. Spaziergang nach Syrakus im Jahre 1802. Leipzig: Ph. Reclam jun., s. a., Ausgabe, (c) eBOOK-Bibliothek für diese Ausgabe.

Shaw, T. R. 1997. »'Many Languages are Understood Here ...' - Foreign Travellers in Slovene Lands." V Un-verständnis der kulturen, Multikulturalismus in Mitteleuropa in historischer Perspektive, uredila M. John in O. Luthar, 31-51. Celovec-Ljubljana-Dunaj: Mohorjeva.

Shaw, T. R. 2007. »The Classical Karst and Its Caves as Known to the Rest of the World Before 1914."Atti e memorie della Commissione »E. Boegan" 41: 47-64.

Shaw, T. R. 2008. Foreign Travellers in the Slovene Karst: 1486-19oo. Ljubljana: ZRC SAZU.

Shaw, T. R., in A. Čuk. 2015. Slovenski kras in jame v preteklosti. Ljubljana: Inštitut za raziskovanje Krasa, Založba ZRC SAZU.

Tobin, J. J. 1832. Journal of a Tour, Made in the Years 1828-1829 through Styria, Carniola, and Italy Whilst Accompanying the Late Sir Humphry Davy. London: W. S. ORR.

Žiberna, J. 1981. Divaški prag. Divača: Svet krajevne skupnosti. 